KUTI Mónika - BEDŐ Zsolt

\title{
AZ EGYETEMI VÁLLALKOZÓI ÖKOSZISZTÉMÁBA ÁGYAZOTT KÖZÖSSÉGI FINANSZÍROZÁS
}

\begin{abstract}
A közösségi finanszírozás a pénzügy, a technológia és a vállalkozás nexusába ágyazva katalizálhatja a - regionális és egyetemen belüli - helyi vállalkozói ökoszisztémát, hozzájárulhat a gazdasági növekedéshez, innovációhoz és munkahely-teremtéshez. Az egyetemeken keletkezó vállalkozói és innovációs potenciál szempontjából a hallgatói, oktatói és alumni startup-ok, valamint a $K+F$ kapacitás számára nyújthat alternatív finanszírozási módot az ún. crowdfunding. A szerzők célja, hogy a vállalkozói ökoszisztémák és a közösségi finanszírozás fontosabb vonásait bemutatva feltárják a közös keresztmetszeteket, interakciókat, továbbá átgondolják egy ilyen platform implementációs lehetőségeit a Pécsi Tudományegyetemen.
\end{abstract}

\section{Kulcsszavak: vállalkozói ökoszisztéma, közösségi finanszírozás, vállalkozásoktatás, crowdfunding}

A vállalkozói ökoszisztéma megközelítés Moore (1993) üzleti ökoszisztémát (business ecosystem) definiáló, taglaló munkájából eredeztethető, aki azon felismerés alapján definiálta a koncepciót, mely szerint a cégek nem ,vákuumban” léteznek, s hoznak üzleti döntéseket, hanem más társadalmi-gazdasági szereplőkkel (beszállítók, versenytársak, finanszírozók, fogyasztók stb.) interaktusban teszik azt. A szereplók közötti kapcsolat, eszmecsere nem feltétlenül formalizált (pl.: szerződéssel körülírt, alvállalkozói kapcsolat), sokkal inkább informális, valamint hasonlít inkább közös tanuláshoz, közös gondolkodáshoz, ko-kreációhoz. Ebben a folyamatban a szereplők nem azért lépnek kapcsolatba a másikkal, mert közvetlen, szerződés által szavatolt, anyagi hasznot remélnek, hanem azért, mert egy adott kérdésben szakértői véleményre, impulzusra, visszacsatolásra, megerősítésre (validálásra) van szükségük, ami nem feltétlenül érett meg egy tanácsadói megkeresésre. Ebben segíthet egy jól múködő, megfelelően nagyszámú, s magas minőségú közösségi finanszírozási platform.

A vállalkozási kapacitásteremtéssel foglalkozó tudományos munkákban a vállalkozói ökoszisztéma szemlélet a kétezres évek elején kezdett megjelenni internetes technológiákkal foglalkozó vállalatok (Zacharakis et al., 2003), startup vállalkozások (Napier et al., 2011), innovációs hálózatok (Malecki et al., 2011; Feld, 2012), valamint gazdaság, s regionális fejlesztés (Isenberg, 2011; Kantis et al., 2011) kapcsán. Jelen írásban a vállalkozói ökoszisztéma definícióját Mason és Brown (2014) munkájából kölcsönözzük, akik részben az előbb felsorolt tudományos közlések szintetizálásából alakították ki a fogalmi keretet:

„A vállalkozói ökoszisztéma olyan egymással öszszeköttetésben, kapcsolatban, interakcióban álló vállalkozó szemléletú egyének, szervezetek (pl.: vállalatok, kockázati tókealapok, bankok), intézmények (egyetemek, állami ügynökségek), koncentrációja, melyben vállalkozásspecifikus folyamatok vannak jelen (új, magas növekedési potenciájú vállalkozások születésének magas foka, magas likvidációs ráta, sorozatvállalkozók, sikeres vállalkozók magas elófordulása), s melyet formális és informális folyamatok múködtetnek, kormányoznak."

A vállalkozói ökoszisztémákat a méretük, földrajzi elhelyezkedésük, kiterjedésük szerint is megkülönbözteti a szakirodalom, ugyanakkor nem tesz különbséget teljesítményükben, minőségük osztályozásában, értékelésében (Fetters et al., 2010). E szerint az ökoszisztéma kialakulhat egy innovatív vállalat, egy egyetemi inkubációs program, egy egyetem, egy város vagy egy régió körül is. Függetlenül attól, hogy mi az ökoszisztéma központja, s hogy mekkora a kiterjedése szükség van egy olyan rendszerre, aminek segítségével elemezhető az ökoszisztéma karakterisztikája, megítélhető a fejlettsége, fenntarthatósága. Az ehhez szükséges koncepciós keretrendszert Isenberg (2011) alkotta meg. A keretrendszer hat irányelvre épül: 


\section{Vállalkozói ökoszisztémára ható tényezők}

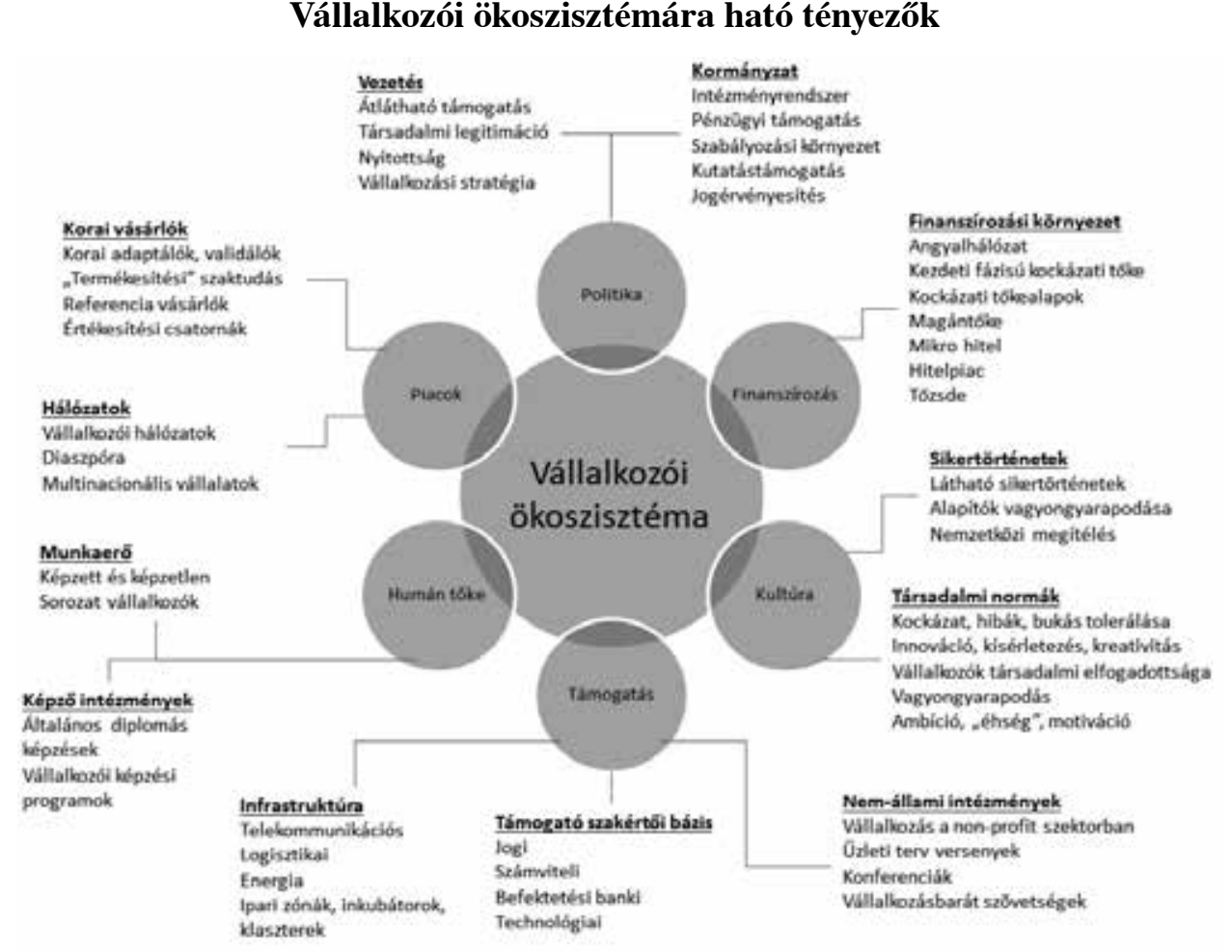

Forrás: Isenberg (2009)

1. különbséget kell tenni az önfoglalkoztató vállalkozó, a kis- és közepes vállalatok és a vállalkozó között,

2. kiemelt prioritást kell kapnia a vállalkozói szemléletnek a közgondolkodásban,

3. az ökoszisztéma-szemlélet holisztikus gondolkodást követel meg,

4. váljék célkitűzéssé, hogy 50.000 - 150.000 lakosonként, minden évben szülessen egy magas növekedési potenciállal rendelkező vállalkozás,

5. az ökoszisztéma földrajzilag koncentrálódjon,

6. az ökoszisztémát létrehozó szerveződésnek ki kell vonulnia az ökoszisztémából egy előre meghatározott időpontban.

Az, hogy egy adott területi egységben milyen minőségú, fenntarthatóságú vállalkozói ökoszisztéma jön létre, több tényezőtôl is függ. Az 1. ábrán látható, hogy Isenberg (2009) hat dimenziót nevesített, mint befolyásoló tényezőket.

Mint minden gazdasági tevékenységnél, úgy a vállalkozók aktivitásánál is kiemelten fontos a gazdaságpolitikai környezet, melyben a szereplők múködnek, támogatást, finanszírozást, jogi biztosítékokat, jogérvényesítési lehetőséget stb. kapnak (kormányzati tényezó). A mindenkori kormányzat gazdaságpolitikai, valamint a monetáris politika pénzügy-politikai döntései a makrokockázaton keresztül közvetlen, s közvetett hatást gyakorolnak az ún. finanszírozási környezetre, amiben a vállalkozók ötleteik finanszírozását, s üzleti koncepcióik validációját végzik. A politikai, gazdaságpolitikai, s pénzügy politikai stabilitás, kiszámíthatóság a finanszírozás költségében jelenik meg közvetlenül, ami a fejlesztések hozamgeneráló képességére hat ki, s alakítja ezáltal a finanszírozók döntéseit. A finanszírozási környezetben az is egy fontos kérdés, hogy a finanszírozók - s itt elsősorban az üzleti angyalokra, kockázati tókésekre gondolunk -, mint az innovatív projektekben elsôdlegesen érdekelt szereplők, milyen formában vesznek részt a projekt fejlesztésében. Csupán forrást juttatnak, ahogy azt a kontinentális európai angyalok teszik vagy üzleti mentorálást, üzletfejlesztési aktivitást is kifejtenek (angolszász modell).

A harmadik befolyásoló dimenzió a vállalkozói kultúra, ami talán az egyik legkritikusabb, s egyben legnehezebben formálható tényező. Milyen a vállalkozók megítélése? Milyen az egyének bukással szembeni attitúdje, hogyan ítéli meg a bukott vállalkozót a társadalmi környezet? Milyen a megítélése a sikeres vállalkozóknak? Milyen a kockázatérzékelési képesség, s a kockázattûrő hajlandóság? Mennyire képesek, s hajlandóak az egyének saját, önálló iniciatívákat megfogal- 
mazni, s megvalósítani azokat? Mekkora a társadalmi s bizalmi tőke? Ilyen és ezekhez a könnyen feltehetó, de annál nehezebben megválaszolható kérdések merülnek fel a kultúra dimenziójában.

A támogatói dimenzióban a támogatói környezet struktúráját, a környezetben múködő szereplóket, s a kvázi facilitátor funkciót ellátó nonprofit szereplőket, lehetőségeket értjük. A vállalkozóknak ötletfázisban lévő projektjeik fejlesztéséhez validációra, hiányzó kompetenciáik kiegészítésére van szükségük, ami nem feltétlenül egy tanácsadó cégtól fog érkezni, hanem sokkal inkább egy kamarától vagy egy vállalkozásfejlesztési alapítványtól, ami eme tevékenységet nonprofit módon végzi, hiszen az ötletfejlesztés e fázisában a projekt tôkevonzó képessége erósen korlátos. A fejlesztés előrehaladtával a profitorientált üzleti, technológiai, jogi tanácsadók szerepe relevánssá válik, aminek anyagi forrása már az elsőkörös finanszírozás eredményeképpen megkeletkezhet. A támogatók e körének felkészültsége, tudásszintje, kapcsolatrendszere jelentős mértékben befolyásolja a vállalkozói projekt növekedési lehetőségeit, ahogy a fejlesztés során a vitális infrastruktúra megléte is.

Az ökoszisztémában felhalmozódott, koncentrálódó tudás-, tapasztalati tőke, készség és képességhalmaz az alapja az innovációs potenciálnak, azaz az újítások valószínúségének. Ezért van jelentős szerepük a felsőoktatási intézményeknek a vállalkozói s innovációs ökoszisztémák kialakulásában. Az egyetem megléte ugyanakkor nem garancia arra, hogy az adott területi egységben magas minőségú ökoszisztéma alakuljon ki, hiszen ha az egyetem nem képes hidat képezni a verseny- és a közszféra szereplóivel (Tripple Helix modell), akkor a gazdasági-társadalmi közeg e dimenziói izoláltan, egymástól függetlenül fognak múködni, tudomást nem véve, $\mathrm{s}$ ezáltal megoldást sem adva, egymás problémájára.

$\mathrm{Az}$ Isemberg-féle rendszerben a hatodik, egyben utolsó befolyásoló dimenzió a piacok dimenziója, ami a keresleten, a beszállítókon, a munkaerôn stb. túl validációt, visszacsatolást ad a vállalkozói projekteknek, ami a majdani keresletmaximálás miatt rendkívül fontos a projektfejlesztésben.

\section{Az alternatív finanszírozás modelljei és karakterisztikái}

A vállalkozói ökoszisztémába szervesen beépülhetnek az alternatív finanszírozás különféle karakterisztikái és üzleti modelljei, hiszen a közösségi finanszírozás három meghatározó szereplője (1) a növekedésből és innovációból eredően külső finanszírozási szükséglettel szembesülő ötletgazdák, kis- és középvállalkozások, (2) a finanszírozandó projekteket kereső forrásjuttatói tömegek és (3) a tranzakciókat lehetővé tevő platform mint piactér. A finanszírozási portálok (funding portal) olyan internetes oldalak, ahol a listázott crowdfunding lehetőségekből válogathatnak az érdeklődő adományozói, a jutalomkereső vagy pénzügyi befektetési céllal rendelkező tömegek. A társadalmi technológiák és a KKV-k tőkeképzésének sajátos összekapcsolásáról van szó. A crowdfunding egyaránt használható tradicionális profitérdekelt vállalkozásokhoz, hagyományos nonprofit vállalkozásokhoz és társadalmi vállalatokhoz (social enterprises), melyek a pénzügyi, környezeti és társadalmi szempontokat egyszerre veszik figyelembe.

Az alternatív finanszírozási platformok újszerúsége abban rejlik, hogy a tradicionális közvetítóket kikerülve adnak helyet a forrásbirtokosok és a forráskeresők közötti direkt interakcióknak. A közösségi finanszírozás „banktalanítja” (debank) és közvetítői tevékenység nélkülivé teszi (desintermediate) a forrásáramlást a tőkejuttatók és a tókefelhasználók között. A közösségi finanszírozási platformok klasszikus értelemben nem disztribúciós közvetítői csatornák, mert nem fogadhatnak el forrásokat a befektetôktől, hanem harmadik félnél letétként jelennek meg a gyújtött források, és nem tarthatnak értékpapírokat részükre, a közösségi finanszírozási portálok azonban információs, kollektivizáló és hírnévalapú közvetítők (Heminway, 2013).

A közösségi platformok által alkalmazott üzleti modellek különféle kategóriákba csoportosíthatók, melyeknek megvan a saját kockázati profiljuk. Bradford (2012) a közösségi finanszírozás öt fajtáját azonosította az adományozási modellek, a jutalommodellek, az elővásárlás-modellek, a hitelezési modellek és a tulajdonositőke-modellek formájában. Az alternatív finanszírozás üzleti modelljeinek egyik kibővített taxonómiáját Collins (2013) fogalmazta meg (1. táblázat). A vállalkozói ökoszisztémában át kell gondolni, hogy mely alternatív finanszírozási modellek iránt van nyitottság, befogadói kultúra és affinitás. A közösségi finanszírozás sajátos iránya az ún. „locavesting”, ami a helyi befektetési lehetôségek és lokális források közötti kapcsolatok létrejöttét támogatja. Különbséget kell tenni ex ante crowdfunding, ahol a pénzügyi támogatás a projekt legelején érkezik, hogy a közösen kívánt célt elérjék, illetve az ex post facto crowdfunding között, ahol egy meglévő termékért cserébe nyújtják a finanszírozást (Kappel, 2009).

A közösségi finanszírozással a pénzügyi érdekeltségek a vállalkozásokban egyre komplexebbé váltak, az értékpapírok és egyéb pénzügyi termékek közötti határok elmosódnak. A crowdfunding korszak beköszöntével a pénzügyi érdekeltség a vállalkozásokban kevésbé jelenik meg tradicionális részvényekben és kötvényekben, helyette a hitelek, a hazardírozó fogadások, valamint a fogyasztási javakhoz vagy szolgál- 
tatásokhoz, vagy adományokhoz, vagy egyéb nonprofit juttatásokhoz való jog a jellemző (Heminway, 2012). A szerző szerint a crowdfunding útján finanszírozott üzleti érdekeltséget leginkább befektetési szerződésnek kell tekinteni. Az értékpapírnak nem minősíthetô (unequity) közösségi finanszírozási érdekeltségek profit- és árbevétel-megosztást tesznek lehetővé kapcsolódó vállalatkormányzási jogok nélkül.

\section{Az alternatív finanszírozás üzleti modelljei}

1. táblázat

\begin{tabular}{|l|l|}
\hline $\begin{array}{l}\text { Adományalapú közösségi } \\
\text { finanszírozás, P2P on-line } \\
\text { forrásgyüjtés }\end{array}$ & $\begin{array}{l}\text { Nincs semmilyen kötelezó erejú pénzügyi kötelezettség az adományozó felé a for- } \\
\text { rást kapó személynél. Azz adományozó nem vár semmilyen pénzügyi vagy anyagi } \\
\text { viszonzást cserébe. }\end{array}$ \\
\hline $\begin{array}{l}\text { Jutalomalapú közösségi } \\
\text { finanszírozás }\end{array}$ & $\begin{array}{l}\text { Az adományozónak olyan várakozása van, hogy a forrásgyújtó materiális (de nem } \\
\text { pénzügyi) jutalmat vagy terméket nyújt a hozzájárulásért cserébe. }\end{array}$ \\
\hline $\begin{array}{l}\text { Részvényalapú közösségi } \\
\text { finanszírozás }\end{array}$ & $\begin{array}{l}\text { Többségében korai fázisú vállalatok regisztrált értékpapírjainak eladása befektetók } \\
\text { számára. }\end{array}$ \\
\hline $\begin{array}{l}\text { Adósságalapú értékpa- } \\
\text { pírok }\end{array}$ & $\begin{array}{l}\text { A hitelezók nem biztosítékolt hitelkötelezettséget kapnak, amit tipikusan hosszabb } \\
\text { időperiódus alatt fizetnek vissza. Hasonló struktúrájában a kötvényvásárláshoz, de } \\
\text { más jogokkal és kötelezettségekkel. }\end{array}$ \\
\hline P2P hitelezés & $\begin{array}{l}\text { Egyének közötti adósságalapú tranzakciók, többségében fedezet nélküli személyi } \\
\text { hitelek. }\end{array}$ \\
\hline P2B hitelezés & Egyének és létezó vállalkozások (főképp KKV-k) közötti adósságalapú tranzakciók. \\
\hline $\begin{array}{l}\text { Számla-kereskedés (invoi- } \\
\text { ce trading) }\end{array}$ & $\begin{array}{l}\text { Vállalatok eladják számláikat vagy követeléseiket egyéneknek vagy intézményi } \\
\text { befektetőknek. }\end{array}$ \\
\hline $\begin{array}{l}\text { Bevétel-/profit-megosztó } \\
\text { közösségi finanszírozás }\end{array}$ & $\begin{array}{l}\text { A kibocsátó kötelezettséget vállal, hogy visszafizeti a hitelezóknek, de ezek a fize- } \\
\text { tések változóak és a cég árbevétele vagy profitja függvényei. }\end{array}$ \\
\hline $\begin{array}{l}\text { Mikrofinanszírozás/ kö- } \\
\text { zösségi részvények }\end{array}$ & $\begin{array}{l}\text { A mikrofinanszírozás arra utal, hogy kis összegekben olyan vállalkozóknak hite- } \\
\text { leznek, akik gazdaságilag hátrányos helyzetúek vagy pénzügyileg marginalizáltak. } \\
\text { Hitelkötelezettséggel jár, de az összegek kicsik. A közösségi részvények olyan tár- } \\
\text { sadalmi vállalkozások részvényeinek eladására utal, melyek közösségi célt szolgál- } \\
\text { nak egy bizonyos helyen. }\end{array}$ \\
\hline
\end{tabular}

A crowdfunding során a forrásjuttatók nemcsak tókét transzferálnak projektek részére, azaz nemcsak pénzügyi megtérülésben gondolkodnak, hanem a közösségi tevékenységbőll társadalmi hasznokra is figyelnek (Belleflamme - Lambert - Schwienbacher, 2013). A közösségi hasznok sokoldalúak lehetnek: kedvezményes hozzáférés múvészekhez és vállalkozókhoz (direkt kommunikáció, a projektfejlesztéssel kapcsolatos szavazás), köszönetnyilvánítások (CD-borítóra írt név, vagy a website-on listába való felkerülés), anyagi jutalmak (póló, eredeti rajz, korlátozott kiadású album, emléktárgyak). A szerzó hármas szerint a vállalkozók inkább a jutalomalapú közösségi finanszírozási formát választják akkor, amikor kisösszegú tôkére van szükségük. Ilyenkor a vállalkozó szegmentálni tudja a vevőket korai jól fizetőkre, akik az előzetes rendelés iránt érdeklődnek és a szokásos vásárlókra, akik megvárják a piacon való megjelenést, ami összességében a magasabb profitrealizálását teszi lehetôvé. Optimális megkülönböztető árazás nem kivitelezhető, ha a tőkeszükség- let túl magas. Profitmegosztó közösségi finanszírozók kevésbé érdekeltek az előzetes rendelésben, cserébe inkább a kapott jövőbeli cash flow-k fontosak.

A közösségi finanszírozás promóciós eszköz is, mely a tömegigényekre való szabottság (mass customization) és a felhasználóra fókuszáló innovációt segíti elő oly módon, hogy a fogyasztók igényeinek jobb megértését teszi lehetővé.

A közösségi finanszírozás párhuzamba állítható az Evans (2011) által megfogalmazott sokoldalú platformok három feltételével. Az első feltétel szerint a fogyasztóknak külön csoportjai vannak jelen, a crowdfunding esetben a vállalkozók mint forrásgyújitók és a tömeg mint forrásjuttató. A második feltétel, hogy minden csoport indirekt, azaz keresztoldali hálózati hatásokat fejt ki a többi csoportra. A vállalkozók számára a platform a kampányok szélesebb választékát ajánlja, míg a finanszírozók számára értékes jutalmakat nyújt. A két oldal kölcsönösen fejt ki pozitív indirekt hálózati hatásokat egymásra, a vállalkozók például azokat a 
platformokat kedvelik, amelyek nagyszámú finanszírozót vonzanak. A harmadik feltétel pedig, hogy a közvetítő hatékonyan koordinálhatja a csoporttagok közötti bilaterális kapcsolatokat.

A közösségi finanszírozás tehát karakterisztikái és üzleti modelljei révén fontos eleme az ökoszisztémának, elősegíti a hálózat tagjai közötti kommunikációt, lehetôvé teszi az üzleti ötletek és a forrásbirtokosok hatékonyabb egymásra találását.

\section{Az egyetemi vállalkozói ökoszisztémába ágyazott közösségi finanszírozás}

A közösségi finanszírozás az ökoszisztémában keletkezett vállalkozói ötletek és innovációk szakaszos finanszírozására is alkalmas a termékötlet validálásával, a prototípus tesztelésével, egyedi felhasználóbázis toborzásával és a problémamegoldásra való fókuszálással. Az innováció gyakran előzetes tudásra épülő exploráció folyamatának eredménye, az emberek olyan hálózatát követeli meg, ahol elismertethetô, fejleszthetô, validálható és értelmes projektté fordítható. Ebben a kontextusban a jutalom és a tulajdonalapú crowdfunding előnyösebb opció lehet a kockázati tôkénél, mert hosszú távú innovációt tesz lehetővé szemben a kockázati tôke gyors exit orientációjával (Serra, 2013). A közösségi finanszírozás során felmerül és kezeletlen marad az innováció dupla bizalom dilemmája, azaz az áttörő ötletek gazdái nem feltétlen fordulnak olyan finanszírozókhoz, akik felhasználhatják az információt az innovátor kompenzálása nélkül (Cooter - Edlin, 2013).

Fontos a bizalom, ami a társadalmi hálózatok megosztott kapcsolatain, közösségi rokonlelkúségen vagy megbízható, mainstream website-okon mások minősítése révén valósul meg. A közösségi finanszírozási platformoknak természetes tendenciája az önszabályozás, a crowdfundinggal kapcsolatos információs aszimmetria, valamint az, hogy a bizonytalanságot saját maguk a saját módjukon kezelik (Belleflamme - Lampert, 2014). Gajda és Banhatti (2013) felmérése alapján a vállalkozók és befektetők 70\%-a egyetértett abban, hogy a közösségi finanszírozásnak - azon túl, hogy projektek és finanszírozók számára kell piacteret nyújtania - eleget kell tennie a pénzügyi és a banki szabályozásnak, tisztában kell lennie a pénzügyi modellezéssel, képesnek kell lennie innovatív stratégiák fejlesztésére és nyitottnak kell lennie a crowdfunding területén megjelenő innovációra. Az ökoszisztémán belül ki kell építeni a mentorálás, a kapacitásépítés, a folyamatos monitoring és a beszámolás rendszerét. A crowdfunding hatékony alkalmazásának tényezői között található a transzparencia mértéke, a kockázatvállalási hajlandóság, a szabadpiaci innováció támogatása, az erős diaszpóra-közösségek a világban (átutalásaik), a korai fázisú vállalkozások aktivitása és a jól múködő oktatás (World Bank, 2013).

$\mathrm{Az}$ egyetemi vállalkozói ökoszisztéma háttérként érték- és hatékonyságnövelő kompetenciahalmazt, valamint tudás- és kapcsolati koncentrációt biztosít. A közösségi finanszírozási projektek képességek és specializációk sajátos halmazát követeli meg: számítógépes tudás, döntésképesség, networking, időmenedzsment, prezentáció, énmenedzselés, csapatmunka, írott kommunikáció/tartalom-kibocsátás, projektmenedzselés, üzleti tervezés, marketingkommunikáció (virális és társadalmi marketing), közösségépítés és menedzselés, crowdfunding szakértelem (modellek, platformok, dinamikák ismerete,; forrásszerzés alapjai) és videókészítés egyaránt kell hozzá (Pais - Castrataro, 2013). Ezek ritkán találhatók meg egyetlen egy emberben, ezért fontos a szervezett képességfejlesztés és csapatmunka. A beágyazottság szempontjából jelentôs szerepet játszanak a környezet kialakításában a co-working helyek, inkubátorok, akkcelerátorok, továbbá a mentorálást, társaktól való tanulás lehetőségét, formalizált termékpiaci illeszkedés kísérleteket, crowdfundingot, vállalkozásteremtést és egyéb támogató szolgáltatásokat létrehozó vállalkozói kultúra.

Belátható tehát, hogy a közösségi finanszírozást szolgáló platformok hatékony múködéséhez elengedhetetlen egy olyan közösség megléte, melynek tagjai ugyanazt a „kódrendszert” használják a napi kommunikációban, ugyanúgy gondolkodnak, hasonló céljaik vannak, s nem utolsó sorban, mint közösség, bizalmi tókével rendelkeznek. E feltételek hiánya azt eredményezi, hogy a platform nem lesz képes megfelelő színvonalú, minôségú projektek vonzására, ami a másik oldal, azaz a finanszírozók, érdeklődők távolmaradását hozza majd. Összefoglalva, nem alakul ki ,gravitációs hatás" a platform körül. A gravitációs hatás kifejlődéséhez, azaz a platform eredményességéhez, elengedhetetlen a vállalkozói ökoszisztéma megléte, kifejlődése s továbbfejlődése. A platform akkor lehet csak sikeres s fenntartható, ha az organikus módon az ökoszisztéma fejlődésének eredményeképpen jön létre, tehát az alternatív finanszírozási igény az ökoszisztéma „tagjai” részéről merül fel, akár a projektgazda, de akár a finanszírozói oldalról.

\section{A közösségi finanszírozásra való felkészültség mérése}

A Simonyi Üzlet- és Gazdaságfejlesztési Központ (Simonyi BEDC) keretében 2014-2015 között zajlott kutatás két irányt próbált feltárni a felmerült közösségi finanszírozási platform igény kapcsán. Egyrészt a vállalkozói inkubációs programokban részt vevő hallgatók téma iránti affinitását mérte programon kívüli hallga- 
tók kontrollcsoportjaival szemben, másrészt az egyetemi vezetők és az ökoszisztémában jelenlevő döntéshozók véleményét kérdezte ki a Világbank (2013) ún. „közösségi finanszírozásra való felkészültség” kérdőívének kitöltetésével és értékelésével.

A hallgatói affinitás felmérésével kapcsolatos kérdốiv 198 diákra terjedt ki: egy harmaduk (35\%) vett részt a Simonyi BEDC hallgatói üzletfejlesztési programjaiban, kétharmaduk nem. Tájékozottsági szintjüket jelzi, hogy az összes megkérdezett hallgató 18\%-a az interneten olvasott már róla, 35\%-uk egyetemi előadásokat hallgatott már a témában. Érdekes, hogy annak ellenére, hogy a hallgatók közel fele még nem hallott a közösségi finanszírozásról, a teljes minta $84 \%$-a véli úgy, hogy múködőképes lenne egy ilyen finanszírozási platform az egyetemi vállalkozói ökoszisztémán belül (2.ábra).

2. ábra

Múködóképes lenne-e egy ilyen finanszírozási platform?

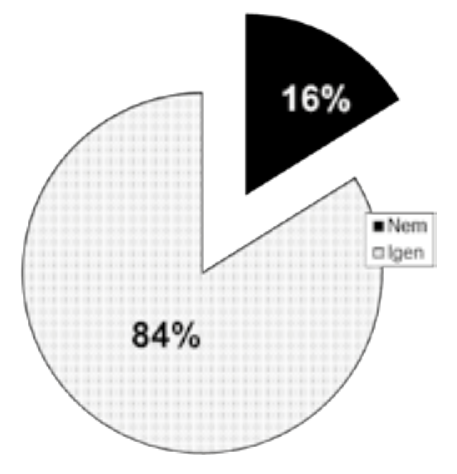

Arra a kérdésre, hogy megjelennének-e finanszírozóként a crowdfunding platformon, választanák-e ezt a befektetési formát, kitúnik, hogy a teljes minta egynegyede vállalná a kezdő vállalkozásokban való tulajdonjog szerzésével kapcsolatos kockázatokat kisebb összeggel (3.ábra). Az üzletfejlesztési inkubációs programokban részt vevő hallgatók között ez az arány $37 \%$, ami egyértelmúen jelzi az egyetemi vállalkozói ökoszisztéma által hozzáadott többletet. Ha abból indulunk ki, hogy az inkubációs programokban részt vevő hallgatók 90\%-a hallott már valamilyen formában a közösségi finanszírozásról, akkor még kontrasztosabb az eredmény. Azon hallgatókat leszúrve, akik nem hallottak még a közösségi finanszírozásról és inkubációs programokban sem vettek részt - ók többnyire levelezős hallgatók, mert alap- és mesterképzésen a nappali pénzügy szakon mindenhol beépítették a curriculumba a közösségi finanszírozás témakörét - azt kaptuk, hogy csupán 16\%-uk mutat hajlandóságot arra, hogy megjelenjen finanszírozóként egy ilyen platformon. Egyértel- múen kimutatható, hogy a téma oktatásának és a vonatkozó ismereteknek a hiánya alacsonyabb befektetési hajlandósághoz vezet.

\section{3. ábra}

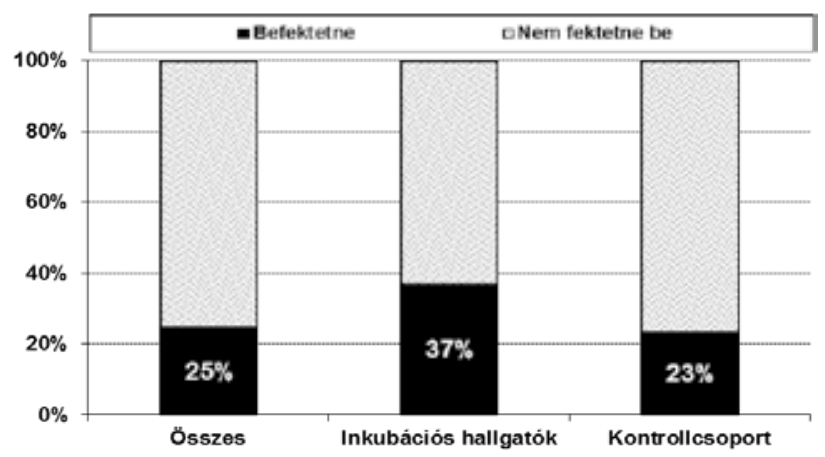

A kérdőív megpróbálta feltárni a hallgatók körüli potenciális finanszírozói holdudvarokat is. Az összes hallgató 44\%-a jelezte azt, hogy a családjában és ismerősei között lennének olyanok, akik befektetnének közösségi finanszírozási csatornákon keresztül.

A kutatás másik iránya a Világbank (2013) által kifejlesztett önértékelési teszt elvégzése volt, ami közelítóleg becsüli meg azt, hogy az adott ország vagy régió milyen mértékben áll készen a közösségi finanszírozás elindítására. 22 egyetemi vezetôt és az ökoszisztémában fontos döntéshozót kérdeztünk meg a tőkéhez való hozzáférés, a technológiai fejlettség, a vállalkozói kultúra és szabályozás dimenziói mentén.

A közösségi finanszírozás vállalkozói ökoszisztémába való beágyazásának és egyetemi bevezetésének legnagyobb akadályaként a vállalkozói életmodell vonzóságával, a kockázatvállalási hajlandósággal, a társadalmi bizalommal és a vállalkozói ismeretekkel kapcsolatos üzleti kultúra mérsékelt fokát határozták meg a vezetôk (4. ábra). Második kihívásként a vállalkozásindítással, -fejlesztéssel és -megszúntetéssel kapcsolatos szabályozás áll. A technológia és a tőke szerepét ítélik meg legkedvezóbbnek a megkérdezettek. Az internet elterjedtsége, a társadalmi médiák használata és az internetes banki szolgáltatások megléte az információs technológiák oldaláról, továbbá a magvető fázistól a banki finanszírozásig terjedő forrásszerzési spektrum a tôke oldaláról támogatja leginkább a közösségi finanszírozás létrehozását. A 4. ábrán látható eredmények átlagaként kapott 6,02-es érték értelmében a világbanki kérdőív értékelése alapján jók az esélyek a közösségi finanszírozás sikeres bevezetésére és a jutalomalapú közösségi finanszírozási üzleti modell ajánlott. 
4. ábra

A közösségi finanszírozásra való felkészültség foka

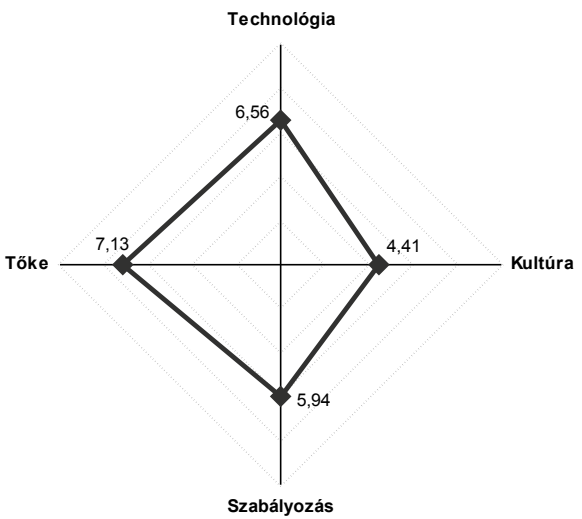

Forrás: saját szerkesztés a Világbank kérdốive (2013, p. 65-67.) alapján

\section{Következtetések}

Az egyetemi vállalkozói ökoszisztémán belül - annak céljaival és felépítésével összhangban -létjogosultsága van egy ún. „locavesting” irányt képviselő közösségi finanszírozási platformnak, ami a vállalkozói ötletkínálat és a forrásbirtokosok közötti interaktivitás révén hatékonyabb helyi erőforrás-allokációt tesz lehetővé, ökoszisztéma-szintú közösségi hasznokat generál, elôsegíti a lokális tốkevonzást és -megkötést, regionális vállalkozói kapacitást és munkahelyeket teremt. A Simonyi BEDC keretében végzett közösségi finanszírozással kapcsolatos kutatások arra világítanak rá, hogy rendkívül fontos a vállalkozói kapacitásteremtésre törekvő hallgatói programok, valamint a közösségi finanszírozással kapcsolatos képzések együttes jelenléte az ökoszisztéma-tagok attitúdformálásában és a vállalkozói kultúra építésében. Az ökoszisztémában fellelhető kompetenciasurrúsödés, a folyamatos vállalkozói ötletgenerálás és az innovációs tevékenység hajtóerőt képeznek a ráépülő közösségi finanszírozás kínálati oldalán, míg a finanszírozói (keresleti) oldalon inkább érzékelhetốk kockázatok. A közösségi finanszírozási modellek közül jelen fázisban a jutalomalapú üzleti modellnek lehet relevanciája Pécsett, az egyetemi vállalkozói ökoszisztéma hatékony múködésében és organikus fejlódésében. A hazai egyetemek gazdaság- és vállalkozásfejlesztésben betöltött szerepének összefüggéseiben a nyugati modellek átültetésének számos kihívással kell szembesülnie a stratégiai, módszertani és kulturális különbségek miatt (Imreh-Tóth, 2015). A 2015 decemberében a Pécsi Tudományegyetemen indult egyetemi közösségi finanszírozási platform (pecs.hubbub.net) ilyen szempontból mindenképpen tesztértékú lesz a két éves „pilot periódus” alatt.

A megkeletkező adatok alapján további kutatási irányt jelent az egyetemi inkubációs és oktatási prog- ramok, valamint az effektív közösségi finanszírozási aktivitás közötti kapcsolat mérése, továbbá az, hogy az egyetemi közösségi finanszírozás, mint niche piac jellemzői mennyiben térnek el a jutalomalapú crowdfunding nemzetközi szakirodalma által meghatározott tényező́ktől.

\section{Felhasznált szakirodalom}

Belleflamme, P. - Lambert, T. - Schwienbacher, A. (2013): Crowdfunding: tapping the right crowd. Journal of Business Venturing, Forthcoming; CORE Discussion Paper No. 2011/32. Available at SSRN: http://ssrn.com/abstract=1578175

Belleflamme, P. - Lambert, T. (2014): Crowdfunding: some empirical findings and microeconomic underpinnings. Available at SSRN: http://ssrn.com/ abstract $=2437786$ or http://dx.doi.org/10.2139/ ssrn. 2437786

Bradford, C. S (2012): Crowdfunding and the Federal Securities Laws. 2012 COLUM. BUS. L. REV. 1: p. 30-42.

Collins, L. - Swart, R. - Zhang, B. (2013): The Rise of Future Finance. The UK Alternative Finance Benchmarking Report. Available at: http://www. funginstitute.berkeley.edu/sites/default/files/Rise_ of_Future_Finance_1_1.pdf

Cooter, R. - Edlin A. (2013): The Double Trust Dilemma: combining ideas and capital. in: Cooter, R. (ed.): The Falcon's Gyre: Legal Foundations of Economic Innovation and Growth. Berkeley Law Books. Available at: http://scholarship.law.berkeley.edu/books/1

Evans, D. S. (2011): Platform Economics: essays on multi-sided businesses. Competition Policy International

Feld, B. (2012): Startup Communities: building an entrepreneurial ecosystem in your city. Hoboken NJ: Wiley

Fetters, M. L. - Greene, P. G. - Rice, M. P. - Butler, $J$ J S. (2010): The Development of University-Based Entrepreunership Ecosystems. London: Edward Elgar Publishing Inc.

Gajda, O. - Banhatti, R.D. (2013): Building a European Crowdfunding Ecosystem. in: European Crowdfunding Network: Towards an Ecosystem for Early-Stage Finance and Innovation Through Crowdfunding. http://www.europecrowdfunding.org/ wp-content/blogs.dir/12/files/2013/12/20131219_ ECN_Towards-an-ecosystem-for-early-stage-finance-and-innovation-through-crowdfunding.pdf

Heminway, J. M. (2012): What is a Security in the Crowdfunding Era? (2012). 7 Ohio St. Entrepren. Bus. L.J. 335 (2012); University of Tennessee Legal Stu- 
dies Research Paper No. 204. Available at SSRN: http://ssrn.com/abstract=2210162

Heminway, J. M. (2013): The New Intermediary on the Block: Funding Portals under the CROWDFUND Act (June 18, 2013). UC Davis Business Law Journal, Vol. 13, p. 177 (2013); University of Tennessee Legal Studies Research Paper No. 219. Available at SSRN: http://ssrn.com/abstract=2293248

Imreh-Tóth Mónika (2015): Vállalkozásoktatási jó gyakorlatok adaptációs lehetôségei a hazai felsőoktatásban - a Szegedi Tudományegyetem példája. Vezetéstudomány, 46, (2): p. 57-67.

Isenberg, J. D. (2011): Introducing the Entrepreneurship Ecosystem: four defining characteristics. Forbes, 2011. May 25. http://www.forbes.com/sites/ danisenberg/2011/05/25/introducing-the-entrepreneurship-ecosystem-four-defining-characteristics/

Isenberg, J. D. (2010): How to Start an Entreprenurial Revolution. Harvard Business Review, June: p. 41-50.

Kantis, H. - Frederico, J. (2011): Entrepreneurial Ecosystems in Latin America: the role of policies. Download from: http://www.innovacion. gob.cl/wp-content/uploads/2012/06/Entrepreneurial-Ecosystems-in-Latin-America_the-role-of-policies.pdf

Kappel, T. (2009): Ex Ante Crowdfunding and the Recording Industry: A Model for the U.S.?, 29 LOY. L.A. ENT. L. REV. 375.

Malecki, E J. (2011): Connecting local entrepreneurial ecosystems to global innovation networks: open innovation, double networks and knowledge integration. International Journal of Entrepreneurship and Innovation Management, 14: p. 36-59.

Mason, C. - Brown, R. (2014): Entrepreneurial Ecosystems and Growth Oriented Entrepreneurship. Background paper prepared for the workshop or- ganised by the OECD LEED Programme and the Dutch Ministry of Economic Affairs, The Hague, Netherlands, 7th November 2013. http://www.oecd. org/cfe/leed/Entrepreneurial-ecosystems.pdf

Moore, J. (1993): Predators and Prey: a new ecology of competition. Harvard Business Review, (May/June): p. $75-86$.

Napier, G. - Hansen, C. (2011): Ecosystems for Young Scaleable Firms. FORA Group

Pais, I. - Castrataro, M. D. (2013): New Forms of Work and New Employment Opportunities. in: European Crowdfunding Network: Towards an Ecosystem for Early-Stage Finance and Innovation Through Crowdfunding. http://www. europecrowdfunding.org/wp-content/blogs. dir/12/files/2013/12/20131219_ECN_Towards-an-ecosystem-for-early-stage-finance-and-innovation-through-crowdfunding.pdf

Serra, M. (2013): Crowdfunding as an Impulse for Innovation. in: European Crowdfunding Network: Towards an Ecosystem for Early-Stage Finance and Innovation Through Crowdfunding. http://www.europecrowdfunding.org/wp-content/ blogs.dir/12/files/2013/12/20131219_ECN_Towards-an-ecosystem-for-early-stage-finance-and-innovation-through-crowdfunding.pdf

WORLD BANK (2013): Crowdfunding's Potential for the Development World. Available at: http://www.infodev. org/infodev-files/wb_crowdfundingreport-v12.pdf

Zacharakis, A. - Shepard, D. - Coombs, J. (2003): The development of venture-capital-backed internet companies: an ecosystem perspective. Journal of Business Venturing, 18: p. 217-231.

A cikk beérkezett: 2015 . szeptember. Lektor által véglegesítve: 2016. január.

\section{E SZÁMUNK SZERZŐI}

Dr. Szász Levente, egyetemi docens, Babes-Bolyai Tudományegyetem; Matyusz Zsolt, egyetemi adjunktus, Budapesti Corvinus Egyetem; Dr. Demeter Krisztina, egyetemi tanár, Budapesti Corvinus Egyetem; Durugy András, címzetes egyetemi docens, Szent István Egyetem, Gödöllő; Kollár Péter, egyetemi tanársegéd, Szent István Egyetem, Gödöllő; Dr. Madarász Imre, egyetemi docens, Szent István Egyetem, Gödöllő; Kozma Miklós, egyetemi adjunktus, Budapesti Corvinus Egyetem; Oláh Réka, egyetemi hallgató,SZIE GAEK, Egészségtudományi Campus, Gyula; Varga Dorottya, doktorjelölt, SZIE EGyRTDI, Gödölloó; Dr. Kuti Mónika, Ph.D. egyetemi adjunktus, Pécsi Tudományegyetem; Dr. Bedó Zsolt, Ph.D. egyetemi adjunktus, Pécsi Tudományegyetem 